Список використаних джерел

1. Дистанційна освіта / http://vnz.org.ua/dystantsijna-osvita/pro

2. Клевец А. Чем отличается онлайн-обучение от дистанционного обучения / https://finacademy.net/materials/article/chem-otlichaetsya-onlajnobuchenie-ot-distantsionnogo-obucheniya

3. Федорук Т. Методика використання інформаційно-комунікаційних технологій в навчальному процесі / https://ru.calameo.com/read/ $005138934 \mathrm{e} 74 \mathrm{~b} 785025 \mathrm{db}$

4. ICT in Education / The Uses of ICTs in Education / https://en.wikibooks.org/ wiki/ICT in Education/The Uses of ICTs in Education

5. Salah-Eddine Kandri How COVID-19 is driving a long-overdue revolution in education / https://www.weforum.org/agenda/2020/05/howcovid-19-is-sparking-a-revolution-in-higher-education/

6. What is ICT in Education / http://www.elmoglobal.com/en/html/ict/01.aspx
References

1. Dystantsiyna osvita / http://vnz.org.ua/dystantsijna-osvita/pro

2. Klevets A. Chem otlichayetsya onlayn-obucheniye ot distantsionnogo obucheniya / https://finacademy.net/materials/article/chem-otlichaetsyaonlajn-obuchenie-ot-distantsionnogo-obucheniya

3. Fedoruk T. Metodyka vykorystannya informatsiyno-komunikatsiynykh tekhnolohiy $v$ navchal'nomu protsesi / https://ru.calameo.com/read/ $005138934 \mathrm{e} 74 \mathrm{~b} 785025 \mathrm{db}$

4. ICT in Education / The Uses of ICTs in Education / https://en.wikibooks.org/ wiki/ICT in Education/The Uses of ICTs in Education

5. Salah-Eddine Kandri. How COVID-19 is driving a long-overdue revolution in education / https://www.weforum.org/agenda/2020/05/howcovid-19-is-sparking-a-revolution-in-higher-education/

6. What is ICT in Education / http://www.elmoglobal.com/en/html/ict/01.aspx Надійшла до редколегії 19.12.20

N. Postoiuk,PhD (Pedagogical Sciences), Assistant Professor; L. Levytska, PhD (Pedagogical Sciences), Associate Professor, Taras Shevchenko National University of Kyiv, Kyiv, Ukraine

\title{
THE USE OF ICT IN THE PROCESS OF DISTANCE LEARNING FOR STUDENTS OF HIGHER EDUCATION INSTITUTIONS
}

The article analyzes the peculiarities of the use of ICT during distance learning. Features of distance learning have been considered, namely its elements, subjects and set of means of realization. The difference between the concepts of "distance learning" and "online learning" has been analyzed and their common and distinctive features have been identified.

The advantages and disadvantages of using ICT in the process of distance learning have been highlighted. The main advantages include flexibility (the ability to present the course material based on training, abilities of students), the ability to implement the latest pedagogical, psychological, methodological developments, convenience (the ability to study at a convenient time, in a certain place, education without separation from the main work, no time constraints for mastering the material), modularity (breaking down the material into separate functionally complete topics), costeffectiveness, the ability to simultaneously use a large amount of educational information by any number of students, interactivity (active communication between group students and teacheri), no geographical boundaries for education.

The world practice of development and use of ICT in education shows a tendency to change the traditional forms of organization of the educational process in the information society. Therefore, information and communication technologies are highly effective tools that allow to give a large amount of information to a greater extent than traditional sources of information, and in a sequence that corresponds to the logic of cognition and the level of perception of a certain contingent of students. Having solved the problems with ICT, it will be possible to use new technologies and raise the learning process to a qualitatively higher level.

Keywords: information and communication technologies (ICT), distance learning, higher education, higher education institutions, teachers, students.

Удк 377.011.3-051:37.015.31:6

DOI: https://doi.org/10.17721/2415-3699.2020.12.12

С. Садовенко, асп., Запорізький національний університет, Запоріжжя ORCID iD 0000-0003-3758-2051

\section{КЛЮЧОВІ УМОВИ РОЗВИТКУ ПСИХОЛОГО-ПЕДАГОГІЧНОЇ КОМПЕТЕНТНОСТІ ВИКЛАДАЧА СПЕЦІАЛЬНИХ ДИСЦИПЛІН ТЕХНІЧНОГО КОЛЕДЖУ}

Проаналізовано проблему розвитку психолого-педагогічної компетентності викладачів спеціальних дисциплін технічних коледжів як визначальний фактор підготовки висококваліфікованого випускника, визначені протиріччя, що існують у системі сучасної методичної роботи. Запропоновано авторську схему науково-методичної роботи технічного коледжу, яка об'єднує компоненти, принципи та функції системи й умови її ефективного функціонування. Сформульовано ключові умови розвитку психолого-педагогічної компетентності викладачів спеціальних дисциплін технічних коледжів: створення в закладі освіти системи науково-методичної роботи, формування внутрішньої та створення зовнішньої мотивації викладачів спеціальних дисциплін до професійної діяльності в технічному коледжі, забезпечення науково-методичної системи закладу освіти інформаційними, технологіями. Зроблено висновок, що втілення в науково-методичний процес технічного коледжу вищезазначених організаційно-педагогічних умов стане фундаментом для подальшого формування й розвитку психологопедагогічної компетентності викладачів спеціальних дисциплін.

Ключові слова: умови розвитку, психолого-педагогічна компетентність, технічний коледж, науково-методична робота.

Постановка проблеми. Система освіти кожної країни певною мірою є відображенням системи суспільства, державності та соціальним портретом одночасно. Коли ми говоримо про успішне функціонування будь-якої освітньої системи, ми маємо на увазі як результат сформоване громадянське суспільство, високий рівень кваліфрікованості кадрів, і, як наслідок, економічно розвинену країну з потужним науковим потенціалом і людськими ресурсами для подальшого розвитку.

Проблеми України в освітній сфері обумовлені багатьма фракторами: історичними реаліями, що спричинили зміну цілих систем, і в освіті в тому числі, недостатнім фінансуванням, очікуванням дива від проведення не завжди виважених і конструктивних реформ, які б мали розв'язати всі проблеми й завдання силою управлінського рішення. $€$ запит суспільства, яке хоче отримати від закладу освіти висококваліфікованого спеціаліста, здатного ефективно працювати на сучасному виробництві, зробити кар'єру, конкурентоспроможного на ринку праці, a $€$ реалії сьогодення: низька академічна успішність певної категорії студентів технічних коледжів, проблеми 3 відвідуванням занять, i, як наслідок, досить низька якість отримуваних дипломів.

Однією із причин зазначеної проблеми є, на наш погляд, відсутність ефективної системи науково-методичної роботи технічного коледжу та необхідних умов щодо забезпечення розвитку, а іноді і формування, психолого-педагогічних компетентностей викладачів спеціальних дис- 
циплін. Якщо більшість викладачів загальноосвітніх дисциплін, які викладають на I-II курсі, закінчували педагогічні заклади освіти або мали суттєву психолого-педагогічну складову у своїй освіті, то майбутніх інженерів, технологів, економістів, зазвичай, не готували для майбутньої викладацької діяльності. Тому на старших курсах технічних коледжів педагогічною діяльністю займаються викладачі, які не мають попередньої педагогічної підготовки й досвіду роботи, але повинні забезпечити високий рівень викладання для підготовки майбутнього фрахівця.

Мета статті: дослідити проблеми розвитку психолого-педагогічних компетентностей викладачів спеціальних дисциплін технічних коледжів, визначити протиріччя, які існують у системі навчальної й науково-методичної роботи закладів фахової передвищої освіти, сформулювати ключові умови розвитку психолого-педагогічної компетентності викладачів спеціальних дисциплін технічних коледжів і розглянути шляхи реалізації зазначених умов у системі науково-методичної роботи.

Аналіз останніх досліджень і публікацій: Проблемам розвитку психолого-педагогічних компетентностей викладача в сучасній системі освіти, визначенням необхідних умов, що забезпечуватимуть їхню реалізацію у системі науково-методичної роботи, присвячені дослідження багатьох вітчизняних і зарубіжних науковців. Аналіз функціонування складових системи методичної роботи ми бачимо в публікаціях К. М. Старченко [6, с. 123]. Проблемам професійного розвитку педагога присвячені роботи $€$. Ж. Мухамединої [3, с. 217], а в дослідженнях В. В. Олійника сформульовано погляд про необхідність повномасштабного впровадження у процес підвищення кваліфікації педагогічних працівників сучасних комп'ютерних технологій навчання [4, с. 363]. Питання професійного вдосконалення педагога, організаційно-педагогічних умов розвитку його компетентностей розглядаються в роботах О.В. Крушельницької, В. О. Лук'янихіна, І. П. Підласого [1; 2; 5]. Проте проблемі визначення умов розвитку психолого-педагогічних компетентностей викладачів саме спеціальних дисциплін технічних коледжів не приділяється достатньої уваги в публікаціях сучасних науковців.

Викладення основного матеріалу. Для того, щоб підготувати висококваліфікованого спеціаліста, сам викладач повинен мати відповідний рівень підготовки. Тут існують певні протиріччя. Перше полягає в тому, що, 3 одного боку, від будь-якого викладача вимагають якість викладання дисципліни, знання методик, активних форм і прийомів роботи, застосування інноваційних технологій тощо, а з іншого - відсутність психолого-педагогічної підготовки такого викладача унеможливлює очікуваний від нього результат і якість роботи. Отже, відсутність або недостатній рівень розвитку психолого-педагогічних компетентностей призводить до суттєвих недоліків у педагогічній діяльності.

Друге протиріччя ми вбачаємо в досить низькій мотивації (вмотивованості) на педагогічну діяльність більшості молодих за досвідом викладачів. На роботу в коледж приходять сформовані особистості, які мають високу самооцінку себе як спеціаліста в певній галузі, деякі зробили кар'єру в інших сферах, на виробництві. Тому усвідомити, що для педагогічної діяльності цього буде замало, їм досить складно. Багато хто починає працювати, маючи непевні спогади про те, як колись викладали їм і маючи досвід, до того ж не завжди позитивний, тільки учня і студента.

Третє протиріччя полягає в тому, що система методичної роботи багатьох закладів освіти достатньо консервативна, а на посадах методистів можуть працювати люди, які самі не мають педагогічної освіти, або мають невеликий стаж педагогічної діяльності й невисоку кваліфікаційну категорію. Тому говорити про модернізацію, інформатизацію освітнього простору, у тому числі в науково-методичній роботі, доводиться лише формально, оскільки самі керівники не завжди володіють сучасними інноваційними технологіями, не вміють, а іноді й не хочуть їх застосовувати практично. І використовуються такі форми роботи, які вже морально і фізично застаріли, а тому й важко сприймаються молодими за досвідом викладачами.

Треба зазначити, що ефективна робота в цьому напрямі можлива лише за наявності сформованої системи. Науково-методична робота - це сучасна система організаційного, наукового, методичного забезпечення неперервного розвитку психолого-педагогічних компетентностей викладача, який може адаптуватись до сучасних змін в освітньому просторі, зберігаючи при цьому власні особливості. Науково-методична робота містить у собі певні компоненти, але системою стає лише тоді, коли між елементами утворюється цілеспрямована взаємодія [3, с. 123]. Погоджуючись із запропонованою К. М. Старченком схемою науково-методичної роботи загалом, вважаємо ії̈ недоліком $€$ те, що зв'язки між компонентами недостатньо ссоомульовані. Наприклад, кінцевий результат роботи залежить від таких конструктивних компонентів системи як цілі, завдання та зміст. Форми та методи роботи чомусь не вважаються факторами, що здатні впливати на кінцевий результат, вони взагалі жодним чином не пов'язані з будь-яким іншим компонентом або складовою системи. На наш погляд, для діагностики, формування й розвитку психолого-педагогічних компетентностей викладачів спеціальних дисциплін технічних коледжів доцільно створити таку методичну систему, яка б ураховувала індивідуальні особливості викладача, його рівень готовності до педагогічної роботи, включала як групові, так і індивідуальні форми роботи, стимулювала викладача до особистісного педагогічного зростання. На рисунку 1 пропонуємо власну схему науково-методичної роботи технічного коледжу, яка об'єднує компоненти, принципи і функції системи й умови ії ефективного функціонування. Усі структурні компоненти системи (цілі та завдання, зміст, форми й методи) спрямовані на реалізацію результату роботи та пов'язані відповідно з умовами, принципами і функціями. Саме цілісність і системність застосування всіх означених складових у комплексі сприятиме досягненню кінцевого результату. Тому ключовою організаційно-педагогічною умовою підготовки викладачів спеціальних дисциплін технічних коледжів ми вважаємо створення в закладі освіти такої системи науково-методичної роботи, що дозволяє розвивати психолого-педагогічну компетентність викладачів спеціальних дисциплін технічних коледжів більш ефективно, тому що лише після набуття необхідних, базових знань і вмінь 3 основ педагогіки, вікової психології, методики викладання молодими за досвідом викладачами можна переходити до подальшого розвитку їхніх психолого-педагогічних компетентностей. Визначення умов розвитку та функціонування будь-якого процесу є надзвичайно важливим. Ураховуючи результати проведеної аналітичної роботи, першою організаційно-педагогічною умовою підготовки та розвитку психолого-педагогічної компетентності викладачів спеціальних дисциплін технічних коледжів, яка витікає з першого протиріччя, ми пропонуємо: - створення в закладі освіти системи науково-методичної роботи, що дозволяє розвивати психолого-педагогічну компетентність викладачів спеціальних дисциплін технічних коледжів. 


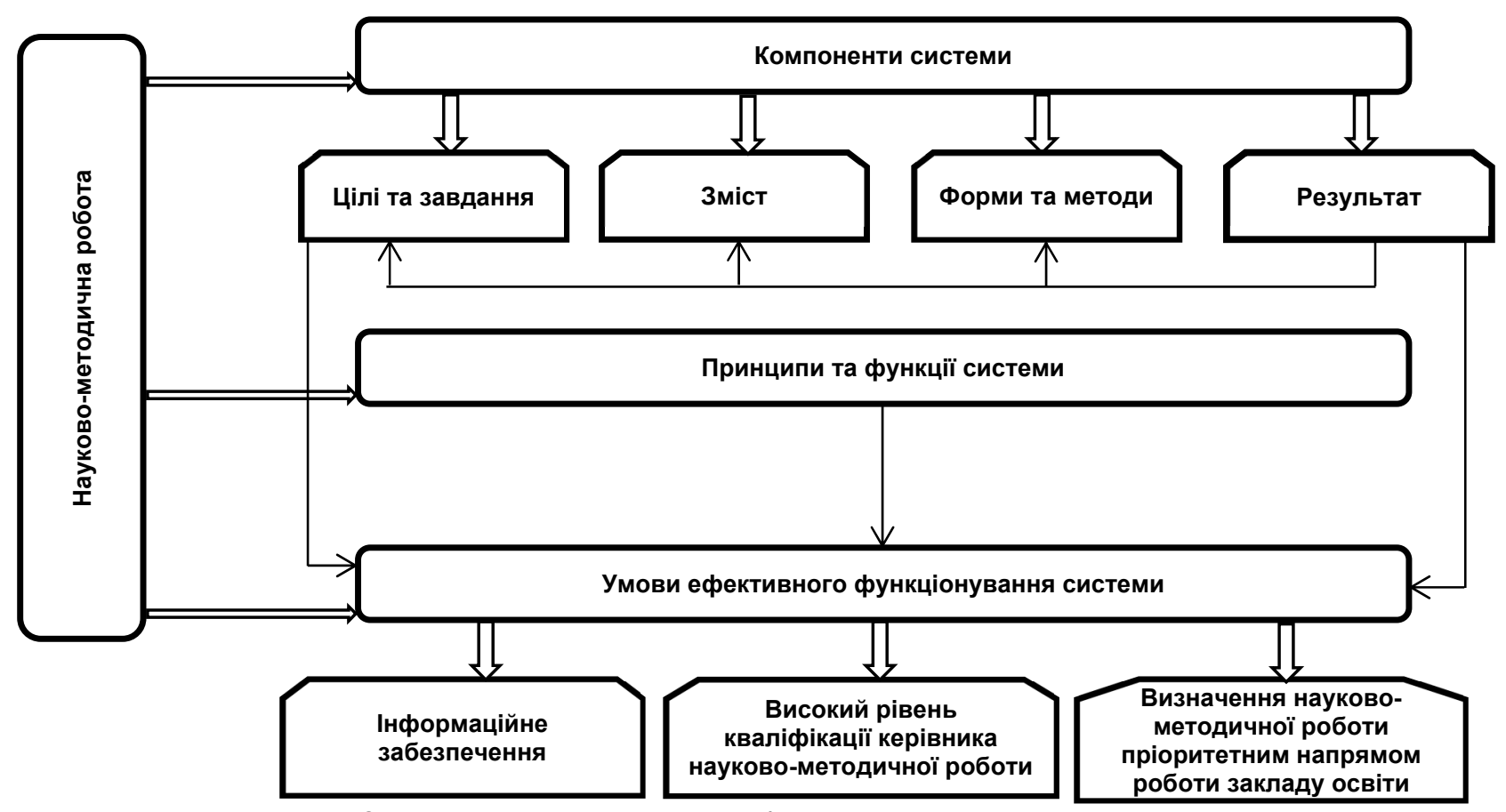

Рис. 1. Система науково-методичної роботи технічного коледжу (дж. - авт.)

Вважаємо, що для узагальнення й науково-методичного обґрунтування досвіду роботи, для забезпечення розвитку психолого-педагогічної компетентності викладачів спеціальних дисциплін технічних коледжів $є$ доцільним розробка та впровадження спецкурсу, у тому числі в дистанційній формі з використанням хмарних технологій, "Розвиток педагогічного потенціалу викладача". Це дозволить провести системне дослідження щодо рівнів психолого-педагогічної компетентності викладачів спеціальних дисциплін технічних коледжів, визначитись із колом питань, що турбують сучасного викладача в його педагогічній діяльності, сприяти розв'язуванню нагальних питань професійного розвитку викладача та формуванню висококваліфрікованого спеціаліста.

Дуже важливим фрактором для становлення початкуючого викладача є морально-матеріальна підтримка педагогічного працівника адміністрацією закладу освіти. На жаль, сучасне законодавство в питаннях оплати праці початкуючого викладача навряд чи може мотивувати, оскільки без доплат за вислугу років (педагогічний стаж), кураторство академічною групою (а без досвіду педагогічної діяльності адміністрація не довірить таку роботу), завідування лабораторією або кабінетом (нема гарантії, що з прийомом на роботу хтось гарантуватиме власний кабінет), заробітна плата майже дорівнюватиме мінімальній. Тому дуже важливо на перших етапах педагогічної діяльності підтримати молодого за досвідом викладача, створити в колективі сприятливий мікроклімат, у якому йому буде комфортно, де не виникатиме відчуття відокремленості, непотрібності. Необхідно, щоб питання, які обов'язково з'являються під час навчальновиховного процесу, своєчасно були сформульовані, озвучені, на які б викладач отримав ґрунтовну та кваліфіковану відповідь. Відвідування навчальних занять, огляд документації, індивідуальні бесіди й консультування дадуть методисту коледжу можливість виявити наявні проблеми, ускладнення та спланувати подальші етапи індивідуальної роботи. Треба пам'ятати, що суцільна критика в цей період неприйнятна, оскільки людина лише опановує абсолютно новий для себе вид діяльності й рухається в цей період швидше інтуїтивно, ніж свідомо. Є випадки, коли перевіряючі особи вимагають від початкуючого викладача таких знань і вмінь, які просто не мали де взятися. Не можна критикувати людину за те, що вона не знає того, чому її ніхто та ніколи не вчив. Єдина мета першої перевірки - надання методичної допомоги, щоб спонукати викладача на подальший професійний розвиток, допомогти повірити у власні сили, здібності, можливості, щоб не знищити бажання взагалі займатися педагогічною діяльністю.

Дуже важливою тут є позиція адміністрації. Залучення початкуючого викладача до обговорення актуальних освітніх питань, активної суспільної діяльності, участі в роботі циклових предметних комісій (тижні комісій, організація та проведення студентських олімпіад, конкурсів, конференцій різного рівня), засіданнях педагогічної ради дозволить початківцю швидше осягнути специфіку освітнього процесу, налагодити контакт із новими колегами та студентами. Треба, щоб викладач відчував, що успіхи в його роботі не будуть непоміченими членами адміністрації та колегами, що його зусилля, ініціативність, прагнення до самовдосконалення обов'язково будуть оцінені, у тому числі й матеріально: майбутнє навантаження, преміювання тощо. А відзнаки за конкретні досягнення та перемоги (власна участь у конкурсах, підготовка студента-переможця) перед членами всього педагогічного колективу, нагородження грамотами та подяками не лише приємні, але й надихають на подальші звершення.

Велику роль у роботі сучасного освітянина відіграють і технічні засоби, без яких організувати якісний навчальний процес дуже важко, а іноді й неможливо. Зрозуміло, що забезпечити весь педагогічний колектив у необхідній кількості та якості комп'ютерною технікою, мультимедійними пристроями, інтерактивними дошками в закладі, який фінансується за рахунок державного бюджету, нема можливості. Тому, на наш погляд, устаткування робочого місця викладача (кабінету, лабораторії) необхідним обладнанням теж може мотивувати до професійного зростання. Отже, другою організаційно-педагогічною умовою підготовки й розвитку психолого-педагогічної компетентності викладачів спеціальних дисциплін технічних коледжів, відповідно до другого визначеного протиріччя, ми вважаємо: 
- формування внутрішньої та створення зовнішньої мотивації викладачів спеціальних дисциплін до профресійної діяльності в технічному коледжі.

Сучасна освіта має потребу в забезпеченні високої якості освітніх результатів за рахунок пошуку внутрішніх резервів самої системи, насамперед використання інформаційних технологій. Виключна роль у розв'язанні цих задач належить викладачам і їхньому рівню психологопедагогічної компетентності. Як вважає $€$. Ж. Мухамедина, професійний розвиток педагога - це безперервний процес і результат свідомого, якісного перетворення себе як суб'єкта професійно-педагогічної діяльності та становлення професійного потенціалу [1, с. 217].

Однією із пріоритетних цілей вдосконалення системи підвищення кваліфікації педагогів є принцип доступності методично-освітніх послуг й орієнтація на індивідуальні потреби кожного викладача. Серед шляхів розв'язання поставлених завдань, на думку В. В. Олійника, доцільно вважати повномасштабне впровадження у процес підвищення кваліфікації педагогічних працівників сучасних комп'ютерних технологій навчання [2, с. 363].

Тому без урахування реалій сьогодення, а саме інформатизації суспільства, сфрер науки й освіти, говорити про професійне вдосконалення викладача недоцільно. У цьому контексті забезпечення взаємодії між учасниками освітнього процесу - викладачами, методистами, членами адміністрації є одним із головних завдань. Існує чимало прикладів розв'язання цієї проблеми, але ми вважаємо, що використання сайту-навігатора та сайту-портфоліо може бути тією складовою організаційно-педагогічної умови, що зробить роботу і методиста, і викладача більш ефективною.

Отже, третя організаційно-педагогічна умова підготовки й розвитку психолого-педагогічної компетентності викладачів спеціальних дисциплін технічних коледжів, що пов'язана з визначеним протиріччям, це:

- забезпечення науково-методичної системи закладу освіти інформаційними, зокрема хмарними, технологіями.

Висновки. Отже, втілення в науково-методичний процес технічного коледжу вищезазначених організа- ційно-педагогічних умов, а саме: створення системи науково-методичної роботи, що дозволяє розвивати психолого-педагогічну компетентність викладачів; формування внутрішньої та створення зовнішньої мотивації викладачів; забезпечення науково-методичної системи закладу освіти інформаційними, зокрема хмарними, технологіями стане фундаментом для подальшого розвитку психолого-педагогічної компетентності викладачів спеціальних дисциплін технічних коледжів, що дозволить сформувати висококваліфікованого педагога, здатного до самовдосконалення, професійного зростання, зацікавленого у підвищенні рівня своєї майстерності і, відповідно, рівні надання освітніх послуг здобувачам закладу фахової передвищої освіти.

Список використаних джерел

1. Крушельницька О.В. Управління персоналом : навч. посіб. / О. В. Крушельницька. - К. : Кондор, 2003. URL: http://sum.in.ua/s/umova.

2. Лук'янихін В. О. Менеджмент персоналу : навч. посіб. / В. О. Лук'янихін. - Суми : ВТД Університетська книга. 2004.

3. Мухамедина Э. Ж. Организационно-педагогические условия подготовки преподавателей военных вузов к профессиональной деятельности / Э. Ж. Мухамедина // Вестн. Оренбург. гос. ун-та. 2015. - № 11 (186).

4. Олійник В.В.Наукові основи управління підвищенням кваліфікації педагогічних працівників профтехосвіти / В. В. Олійник. - - К. : Міленіум, 2003.

5. Підласий І.П. Діагностика та експертиза педагогічних проектів : навч. посіб. / І. П. Підласий. - К. : Україна, 1998.

6. Старченко К. М. Управління інноваційним розвитком районного (міського) методичного кабінету : наук.-метод. посіб. / К. М. Старченко та ін. - Чернівці : Букрек, 2010

References

1. Krushelnytska O.V. Personnel management: textbook. way / O. V. Krushelnytska. - K. : Kondor, 2003.

2. Lukyanikhin V. O. Personnel management: textbook. way / V.O .Lukyanykhin. - Sumy: VTD University Book. 2004.

3. Muhammadina E. J. Organizational and pedagogical conditions for the training of teachers of military universities to professional activities / E. J. Muhammadina // Vestn. Orenburg. state un-ta. 2015. - № 11 (186).

4. Oliynyk V. V. Scientific bases of management of professional development of pedagogical workers of vocational education: monograph / V. V. Oliynyk. - K. : Millennium, 2003.

5. Podlasy I. P. Diagnosis and examination of pedagogical projects: textbook. way / I. P. Podlasy; International Renaissance Foundation. - K. : Ukraine, 1998.

6. Starchenko K. M. Management of innovative development of the district (city) methodical office: scientific method. way/ K. M. Starchenko and others. - Chernivtsi : Bookrek, 2010

Надійшла до редколегії 03.02.20

S. Sadovenko, postgraduate,

Zaporizhzhya National University, Zaporizhzhya, Ukraine

ORCID iD 0000-0003-3758-2051

\section{KEY CONDITIONS OF DEVELOPMENT OF PSYCHOLOGICAL-PEDAGOGICAL COMPETENCE OF TEACHERS OF SPECIAL DISCIPLINES OF TECHNICAL COLLEGE}

The article analyzes conditions of development of psychological and pedagogical competence of teachers of special disciplines of technical colleges as a determining factor in the preparation of a highly qualified graduate.

An author's scheme of scientific and methodological work of a technical college is proposed, which combines components, principles and functions of the system and conditions of its effective functioning, in which all structural components of the system (goals and objectives, content, forms and methods) are aimed at realizing the result of work and associated with the conditions, principles and functions, and the integrity and systematic use of all the components identified in the complex will contribute to the end result.

It is emphasized that an important factor for becoming a beginning teacher is the moral and financial support of a pedagogical employee by the administration of an educational institution. The priority goal of improving the teachers training system is the principle of accessibility of methodological-educational services and orientation to the individual needs of each teacher, and among the ways of solving the set tasks - full-scale introduction of modern computer technologies of teaching.

The key conditions for the development of psychological and pedagogical competence of teachers of special disciplines of technical colleges have been formulated, namely: the creation of a system of scientific and methodological work in the educational establishment, which allows to develop the psychological and pedagogical competence of teachers of special disciplines of technical colleges, the formation of internal and external disciplines of teaching professional activity in a technical college, providing scientific and methodological system of educational establishment with information, in particular clouds technology.

It is concluded that the implementation of the above-mentioned organizational and pedagogical conditions into the scientific and methodological process of the technical college will become the foundation for the further formation and development of the psychological and pedagogical competence of teachers of special disciplines.

Keywords: developmental conditions, psychological and pedagogical competence, technical college, scientific and methodology. 